\title{
Detaching: Now If the Good Goes
}

\author{
Gabriel Miranda Nava* \\ Chief of Neurology of the Hospital Center of the Presidential General Staff, Mexico
}

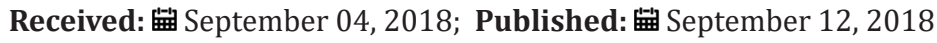

*Corresponding author: Gabriel Miranda Nava, Chief of Neurology of the Hospital Center of the Presidential General Staff, Mexico

\section{Opinion}

The last time we talked about attachments as a powerful glue that we apply to a couple, object, idea, to name a few, and that knowing that we can separate would take us from just thinking about it to a series of curses and disappointments of our life, when never, we have never been closer to wisdom, and that word is so adulterated that it is happiness. Whenever a patient arrives at my office with an anxiety reaction and some depressive episode due to a love breakup, at the moment of knowing their history it is evident that it was a good thing to have that break, because we agree that when listen to someone talk about a relationship, one immediately knows when the protagonist can do well or badly, little by little?, one can think "... what a nice relationship they have" or a "go on, they do it as they want". And that's when at the beginning of my analysis to your talk, one mentions to the patient that he lives a fortunate moment, and they turn to me to see with the most unbelieving eyes of the world world, and they tell me with a "but how do you think that? It is the worst moment of my life ", and I would like to point out that a moment of suffering is the best crystal with which we can visualize a situation, if we are resolute enough despite the moment we are living, it is to take advantage of that cold and painful wave that we It allows us to obtain that resistance that we would not do otherwise.

Since it is the principle to obtain that unique power that human beings have, and of which even the angels lack, the principle of free will, of being able to do what we want, and decide which way to go. That is the way to grow, to decide with the respective consequences, is what makes us great, regardless of our virtues, since what distinguishes us is our way of choosing; and the courageous sister of the decision is detachment. Let us understand the detachment as letting go, letting go, being screwed, not knowing and being worth the sorbet that was what happened, is turning our backs and following our path to that deep-rooted attachment. Do you want to have the power in relationships? It's true, you have to be a lady or a gentleman, you have to support our partner, yes; You have to be attentive and be a good guy, yes, but you also have to arrive with your suitcases, know to go immediately to detect an action or situation that we know we can not tolerate, that is harmful and that is not negotiable: go to Cats work is negotiable, it is to go to America or Toluca, it is to vote for one party or another, but it is not negotiable infidelity, aggression, violence in its various presentations, addictions, the constant lack of overcoming work , also called roe, or be a person with bad habits of hygiene and health. Only one chooses, only one chooses, and we must assume the consequences, since in our country we are accustomed to being victims, to delegate our guilt to others, to say that one is the good and the other the bad, etc., but We never take responsibility, and those actions will never make us grow. Do you want to be a real man, or a whole woman? Use your choices, be responsible, assume the consequences and you will see a new dawn.

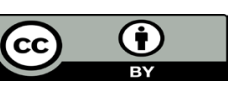

This work is licensed under Creative Commons Attribution 4.0 License

To Submit Your Article Click Here: Submit Article

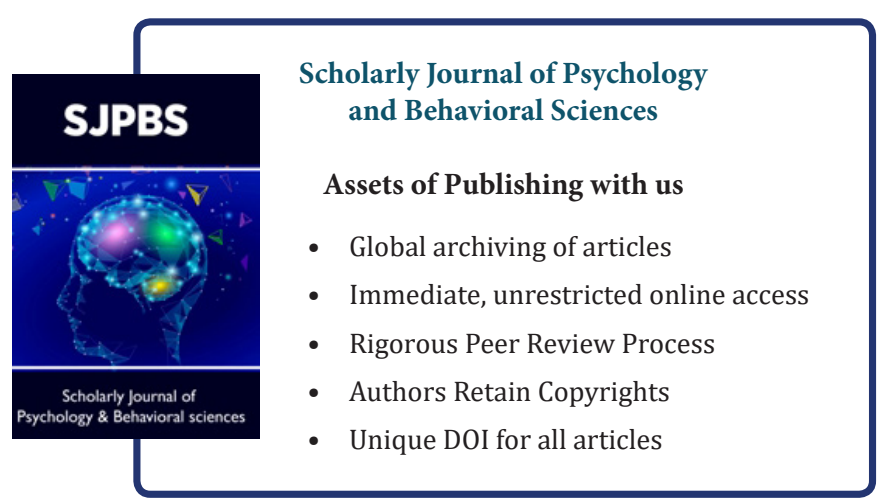

